\title{
Proposal for a terrane-based nomenclature for the Lewisian Gneiss Complex of NW Scotland
}

\author{
P. D. KINNY ${ }^{1}$, C. R. L. FRIEND ${ }^{2}$ \& G. J. LOVE ${ }^{1}$ \\ ${ }^{1}$ Tectonics Special Research Centre, Department of Applied Geology, Curtin University of Technology, GPO Box U1987, \\ Perth, W.A. 6845, Australia \\ 245, Stanway Rd., Risinghurst, Headington, Oxford OX3 8HU,UK (e-mail: crlfriend@yahoo.co.uk)
}

\begin{abstract}
The current nomenclature for the Lewisian Gneiss Complex has evolved from lithological and structural correlations made prior to any dating. Initial (flawed) geochronological studies gave some names an apparent chronological standing but, as work advanced, fitting events into a coherent regional framework became increasingly difficult. Modern dating studies have shown that the Lewisian Gneiss Complex was progressively assembled from disparate blocks of Archaean continental crust and juvenile Proterozoic arcs, which satisfy the definition of terranes. Each terrane had its own separate accretionary and metamorphic history followed by a common history once juxtaposed against other terranes. Based on a new compilation of modern geochronology allied to the many detailed structural and metamorphic studies, this paper proposes a new systematic terminology for the Lewisian Gneiss Complex that is more applicable to this new tectonic framework.
\end{abstract}

Keywords: Lewisian Gneiss Complex, Archaean, Proterozoic, terranes, geochronology, nomenclature.

Historically, the Lewisian Gneiss Complex of NW Scotland has importance as the first region of Precambrian basement rocks to be correctly interpreted as an exhumed section through the lower crust (Peach et al. 1907; Sutton \& Watson 1951). As such, the Lewisian has been used as a model for numerous other highgrade gneiss complexes (e.g. Park \& Tarney 1973) and as an exemplar of lower-crustal processes in general (e.g. Rollinson \& Windley 1980; Tarney \& Weaver 1987).

Initially, the basement gneisses were called the 'Fundamental Gneiss' by Murchison, followed by the pioneering field mapping that led to 'stratigraphical' and geographical subdivisions (Peach et al. 1907). Subsequently, the structural and metamorphic subdivisions of Sutton \& Watson (1951) were presented, in which the Lewisian was viewed as a contiguous block of Archaean crust that experienced two major 'orogenic cycles'. The first of these, called the Scourian, was characterized by granulite-facies metamorphism, and the second, termed the Laxfordian, was characterized by amphibolite-facies metamorphism with variable reworking localized upon shear zones (Sutton \& Watson 1951, 1962, 1969; Moorbath \& Park 1971; Davies \& Watson 1977; Park \& Tarney 1987; Park et al. 1994). Using Rb-Sr geochronology Giletti et al. (1961) first demonstrated that the gneiss complex contained rocks of Archaean age. Subsequent wholerock and mineral dating (Moorbath et al. 1969) was interpreted to suggest that the Scourian event occurred in the late Archaean, and that the Laxfordian event occurred in the Proterozoic. It was considered that the two episodes were separated by intrusion of mafic dyke suites (the Scourie dykes), a view followed by many later workers (e.g. Pidgeon \& Bowes 1972; Chapman \& Moorbath 1977; Whitehouse 1988). Later, the term Inverian was introduced, describing a period of deformation and retrogression affecting some of the Archaean granulites prior to the intrusion of the Scourie dykes (Evans \& Tarney 1964; Evans 1965). This work was initially based on the Scottish mainland before being extended to include the Outer Hebrides.

The mainland was subdivided into three geographical regions: 'northern', 'central' and 'southern' (Peach et al. 1907; Sutton \& Watson 1951, 1962, 1969). The central region was interpreted as one in which Laxfordian reworking had least affected the older gneisses such that granulite-facies assemblages from the Scourian event were extensively preserved. The northern and southern regions were those in which the effects of Laxfordian deformation and metamorphism were more prevalent, and the gneisses were considered to have lost their 'Scourian character' (e.g. Davies \& Watson 1977; Park et al. 1994).

This threefold subdivision on the Scottish mainland has underpinned all modern studies of the Lewisian (e.g. Moorbath \& Park 1971; Davies \& Watson 1977; Park \& Tarney 1987, Park et al. 1994; Corfu et al. 1994, 1998; Friend \& Kinny 1995; Rollinson 1996) and is still in use (e.g. Droop et al. 1999; Burton et al. 2000; Park et al. 2001). Unfortunately, it was founded on the incorrect assumption that all of the gneisses of the complex were roughly contemporaneous and cogenetic and that, to varying degrees, all have experienced the same tectonothermal history. Modern $\mathrm{U}-\mathrm{Pb}$ geochronology has now shown this to be not the case (Friend \& Kinny 2001; Love et al. 2004).

In the last 20 years a revolution has occurred in geochronology with the development of ion microprobes and their application to the dating of zircons and other U-bearing minerals (e.g. Williams 1998, and references therein). In combination with modern mineral imaging techniques, this technology has made it possible to identify and date age components present within mineral grains in situ, often discriminating multiple events in the history of a single rock sample (e.g. Friend \& Kinny 1995). When applied to the Archaean gneiss complex of West Greenland, zircon geochronology in conjunction with careful fieldwork showed unequivocally that the complex was not one major crustal domain as previously thought, but was tectonically constructed in the late Archaean from blocks of crust that had radically different origins and histories (e.g. Friend et al. 1988, 1996). Subsequently, similar relationships have been found in other Archaean gneiss complexes, such as the Narryer Gneiss 
Complex of Western Australia (Nutman et al. 1993), and now the Lewisian Gneiss Complex (Friend \& Kinny 1995, 2001; Kinny \& Friend 1997; Love et al. 2004), suggesting that such relationships may be typical of Archaean high-grade gneiss terranes worldwide. In the case of the Lewisian, tectonic assembly of separate terranes appears to have occurred in the Palaeoproterozoic (Friend \& Kinny 2001), during which time a number of juvenile crustal components were also added (e.g. Cliff et al. 1983, 1998; Cliff \& Rex 1989; Park et al. 2001; Whitehouse \& Bridgwater 2001). Hence the old idea of a variably reworked block of single-aged Archaean crust is now untenable and, as a result, a complete revision of the terminology used to describe the tectonic architecture and history of the Lewisian Gneiss Complex is urgently required.

The principal aim of this paper is to present a revised and extended nomenclature for the Lewisian Gneiss Complex based upon the new understanding of the tectonic architecture of the complex (Friend \& Kinny 2001; Love et al. 2004). This new understanding stems primarily from the recognition of spatial associations of rock units and events dated accurately by in situ single-zircon U-Pb geochronology (e.g. Friend \& Kinny 1995; Kinny \& Friend 1997; Whitehouse et al. 1997; Whitehouse \& Bridgwater 2001; Love et al. 2004). Also contributing to the synthesis are data from other modern single-grain and wholerock geochronological methods (e.g. Corfu et al. 1994, 1998; Whitehouse et al. 1996; Park et al. 2001) as well as lithological and structural studies (e.g. Khouray 1968; Bowes et al. 1971; Gillen 1975; Park 2002).

\section{Problems with the existing nomenclature}

This paper is not the first to point out problems in the nomenclature used to describe the geology of the Lewisian Gneiss Complex. Throughout the history of its investigation, understanding the evolution of the Complex has been impeded by problems of conflicting and inconsistent nomenclature and failed attempts to correlate rocks, structures and events across the complex as a whole. As articulated by Bowes (1978, p. 70): 'The stratigraphical nomenclature and subdivisions used in relation to the Lewisian complex over more than a quarter of a century have been so varied and so confusing that all but those involved in research must have found terminology a great hindrance to comprehension of fundamental principles illustrated by the development of the complex.' Outlined below are some of the principal reasons why such difficulties have arisen.

(1) Problems arose at an early stage from the initial misconception that the grey quartzo-feldspathic gneisses that form most of the complex represented metamorphosed sediments and/ or volcanic rocks rather than plutonic igneous rocks. Sutton \& Watson (1951) proposed that the grey gneisses comprised largely melted sediments. Conversely, Bowes et al. (1971) argued that the gneisses were largely felsic volcanic rocks, a view supported by Sheraton et al. $(1973 a, b)$ based on copious geochemical data. However, following the conceptual breakthrough by McGregor (1973), it became accepted that most of the quartzo-feldspathic gneisses were derived from deformed plutonic rocks of tonalitetrondhjemite-granodiorite (TTG) affinity (e.g. Bridgwater et al. 1973; Moorbath 1977; Bowes 1978; Rollinson \& Windley 1980). Numerous names established on the basis of a supposed stratigraphic sequence, e.g. the 'Kylesku group' (Khouray 1968; Barooah 1970; Chowdhary \& Bowes 1972), were no longer suitable for describing an essentially plutonic complex. Additionally, some groupings of rocks were defined according to their metamorphic mineral assemblages (e.g. Holland \& Lambert
1973). This was always likely to be difficult to use, particularly as the polyphase metamorphic evolution became more evident.

(2) Over time, key terms such as Scourian and Laxfordian were broadened and modified from their original definitions. This occurred as it was found that the 'orogenic cycles' to which they refer were more complicated and variable than originally conceived. Qualifying terms such as 'early' and 'late' were added (e.g. Sutton \& Watson 1962, 1969; Park 1970), and confusion arose from the fact that the term Scourian, for example, was being used for 'gneisses, rocks, metamorphism, metamorphic episodes, times and periods' (Evans \& Lambert (1974, p. 150). As later explained by Park et al. (1994), 'the concept arose of Scourian rocks, formed during Scourian time'. Simultaneously, as more detailed studies of different parts of the complex were undertaken, increasingly conflicting views on the geology arose among research groups, accompanied by new and conflicting terminologies. Park (1970, p. 379) explained the problem thus: 'The interpretations of Sutton, Watson and Dearnley on the one hand, and of Bowes on the other, show quite remarkable differences - to the extent that a reader could be excused for thinking that two quite separate areas were being discussed.' However, recorded discussions appended to the papers of Bowes (1971) and Park (1971) indicate that opinions remained irreconcilable.

(3) Early geochronological studies, rather than clarifying age relationships, generally produced imprecise, and in worst cases, inaccurate results, largely as a result of the misapplication of isochron techniques, and limited understanding of the behaviour of isotopic systems in regions of complex geology (e.g. see discussion by Whitehouse et al. 1996). Whole-rock $\mathrm{Pb} / \mathrm{Pb}, \mathrm{Rb}-$ $\mathrm{Sr}$ and, later, Sm-Nd geochronology was carried out on the assumption that all the gneisses across the region were cogenetic (e.g. Moorbath et al. 1969; Moorbath \& Park 1971; Hamilton et al. 1979). It was commonplace for non-cogenetic rocks and rocks of contrasting metamorphic state, including granulite-facies, retrogressed granulite-facies and amphibolite-facies rocks, to be plotted together to produce spurious composite isochrons (e.g. Hamilton et al. 1979). Mixed ages of doubtful geological significance were also generated by early $\mathrm{U}-\mathrm{Pb}$ zircon studies that were based on the combined analysis of multiple grains. For example, a study of the Scourian granulites of the central region (Pidgeon \& Bowes 1972) interpreted a c. 2660 Ma concordia intercept age as dating the granulite-facies 'Badcallian' event on the assumption, now known to be erroneous, that all of the zircons in the two samples had grown during the metamorphism; i.e. that there were no primary igneous or inherited grains present in the analysed mineral fractions. The age derived from the Pidgeon \& Bowes (1972) work was carried through into subsequent studies without comment (e.g. Chapman \& Moorbath 1977; Lyon \& Bowes 1977; Whitehouse 1988) until it was proven that those zircon populations were mixtures of primary and secondary age components, and that the composite age was of no direct geological significance (Friend \& Kinny 1995). The further aspect of matching radiometric ages with the precise timing of development of rock fabrics was lamented by Holland \& Lambert (1995): 'This inability to equate well-defined structural elements in a complex deformational pattern with radiometric age dates is a characteristic and often insurmountable problem in the Lewisian. It also characterizes many other Archaean and Proterozoic areas of the world where partially appreciated structural histories are given enhanced credibility by an arbitrary but persuasive allocation of absolute ages that may, in themselves, be analytically accurate but only indistinctly related to the episode in question.' 
(4) Lack of consensus on the nature and locations of the boundaries separating the three regions on the mainland resulted in them being given different names and geographical locations over time. For example, the boundary between the central and southern regions has been depicted as occurring in a variety of places. Following the work of Sutton \& Watson (1951), Moorbath \& Park (1971, fig. 1) placed the boundary south of Gruinard Bay. Conversely, both Park \& Tarney (1987, fig. 1) and Rollinson (1996, fig. 1), showed the boundary as lying at the north end of Gruinard Bay, but in their text described it as lying south of Gruinard Bay along the 'Gruinard Front', whereas Park et al. (2001, fig. 7) depicted it as lying along the 'Gruinard belt'. This uncertainty was due largely to the discovery of granulitefacies rocks in the vicinity of Gruinard Bay (Crane 1978; Field 1978; Fowler 1986) that previously had been overlooked (e.g. Holland \& Lambert 1973; Davies 1977). Once recognized, these granulites were associated with those occurring in the central region in the vicinity of Scourie and Badcall Bay (e.g. Crane 1978; Park \& Tarney 1987; Park et al. 1994). It was logical, therefore, that the southern boundary of the 'central region'lay somewhere beyond the southernmost preserved granulites. However, the granulite-facies metamorphism at Gruinard Bay is now dated at c. $2730 \mathrm{Ma}$ (Love et al. 2004), i.e. significantly earlier than the c. 2490 Ma granulite-facies metamorphism that affected the gneisses around Scourie and Badcall Bay (e.g. Friend \& Kinny 1995; Kinny \& Friend 1997). On the basis of new geochronology (Love et al. 2004), the best candidate for the boundary now is the Strathan Line (Evans \& Lambert 1974), an imbricated shear zone with a sinistral, top-to-the-north sense of movement. This juxtaposes flat-lying granulites of $2730 \mathrm{Ma}$ age over retrogressed granulites at Lochinver with the metamorphic overprint of 2490 Ma. Furthermore, the indicated protolith ages (see Friend \& Kinny 1995; Love et al. 2004) and geochemical characters (e.g. Fowler 1986) of the Gruinard and Assynt gneisses are also different, implying that the two packages of crust are unrelated.

(5) Attempts to correlate the Lewisian rocks of the Scottish mainland with those on the Outer Hebrides were also problematic, most notably on the Isle of Lewis from which the complex takes its name (see Fettes et al. 1992). Once Archaean ages were obtained from grey gneisses on Lewis, Harris and the southern isles (e.g. Pidgeon \& Aftalion 1972; Moorbath et al. 1975), the Hebridean rocks were automatically considered to be equivalent to those on the mainland and to have had a 'Scourian' history (e.g. Coward 1972; Fettes \& Mendum 1987; Fettes et al. 1992) followed by a 'Laxfordian' history (e.g. Watson 1969; Coward 1973; Lisle 1977; Fettes et al. 1992). However, the threefold subdivision of the mainland exposures into northern, central and southern regions was not readily transferrable to the Outer Hebrides, and early attempts to correlate the geology across the Minch based on similarities of structural style and metamorphic grade (e.g. Dearnley 1962) were largely unsuccessful. It is now clear that certain aspects of the geology of the complex are unique to the Outer Hebrides, such as the occurrence of Proterozoic UHT granulites on Harris (e.g. Cliff et al. 1983, 1998; Cliff \& Rex 1989; Friend \& Kinny 2001; Whitehouse \& Bridgwater 2001). Thus it now appears that there is evidence for closer geological ties between the Outer Hebrides and parts of East Greenland than with the Scottish mainland (Friend \& Kinny 2001).

\section{A new nomenclature for the Lewisian Gneiss Complex}

This proposal is based on the concept that the Lewisian Gneiss Complex is composed of different terranes sensu Coney et al.
(1980), which were amalgamated progressively during the Proterozoic (Friend \& Kinny 2001). It is emphasized that the terranes recognized are formed of packages of rocks that have distinct geochronological histories. In each of these terranes there is an initial accretion phase and a subsequent metamorphic and deformational history. Then, at some point, the blocks were assembled and they began to have a common history. The boundaries between the blocks, now manifest as shear zones, represent these early crustal detachments and sutures. However, some boundaries remained active or were reactivated at later times, destroying kinematic evidence as to original movement directions.

In proposing a revised terrane-based nomenclature, we have introduced new terms for packages of rocks and events relevant to particular terranes, modified the meanings of key classical terms (e.g. Inverian and Laxfordian) in order to match them more closely to well-defined, precisely dated events affecting specific parts of the complex, and abandoned terms such as Scourian whose meanings have been too modified to be readily adaptable to the new scheme. A list of obsolete terms is given in the Appendix.

\section{Revised status of key classical names}

Lewisian Gneiss Complex. This is the general name for all Archaean and Proterozoic basement gneisses of the NW Scotland mainland and Outer Hebrides (Fig. 1). This term includes all rocks that lie underneath the Neoproterozoic Torridonian cover sequence, which have suffered polyphase metamorphism and deformation, largely before c. $1600 \mathrm{Ma}$. Although a useful collective name for the complex as a whole, it groups together non-cogenetic rock packages and carries no strict age connotation beyond the implied Precambrian age of all the rocks.

Scourian. (Sutton \& Watson 1951). Abandoned (see Appendix).

Badcallian (Park 1970). This term was originally applied to the then supposed earliest recognized granulite-facies tectonothermal event affecting the entire complex (formerly known as "early Scourian'). It was thought to have occurred at c. 2700-2660 Ma (e.g. Moorbath et al. 1969; Moorbath \& Park 1971; Pidgeon \& Bowes 1972), but is now dated at c. 2490-2480 Ma (Humphries \& Cliff 1982; Friend \& Kinny 1995; Kinny \& Friend 1997; Love et al. 2004) and is recognized in the Assynt terrane only.

Inverian (Evans 1965). This term is derived from the type area at Lochinver and describes a period of amphibolite-facies retrogressive metamorphism and deformation that occurred after the Badcallian granulite-facies metamorphism and before emplacement of the Scourie dykes. The Inverian retrogression appears to occur most intensely within the juxtaposed margins of the Assynt and Gruinard terranes and is interpreted as reflecting that suturing event. The precise age and overall regional extent of the Inverian event are as yet poorly known.

Scourie dyke suite (Sutton \& Watson 1951). Originally conceived as one swarm and so a useful time marker, the Scourie dyke suite is now understood to comprise at least four petrogenetic suites of mafic and ultramafic dykes (e.g. Tarney 1987) emplaced in a minimum of two magmatic episodes. Although dykes occur throughout the complex, only two from the Assynt terrane have been dated precisely (baddeleyite $\mathrm{U}-\mathrm{Pb}$ ages, Heaman \& Tarney 1989). Ages of $2418 \pm 7 \mathrm{Ma}$ and $1992 \pm 3 \mathrm{Ma}$ were obtained from a bronzite picrite and an olivine microgabbro dyke, 


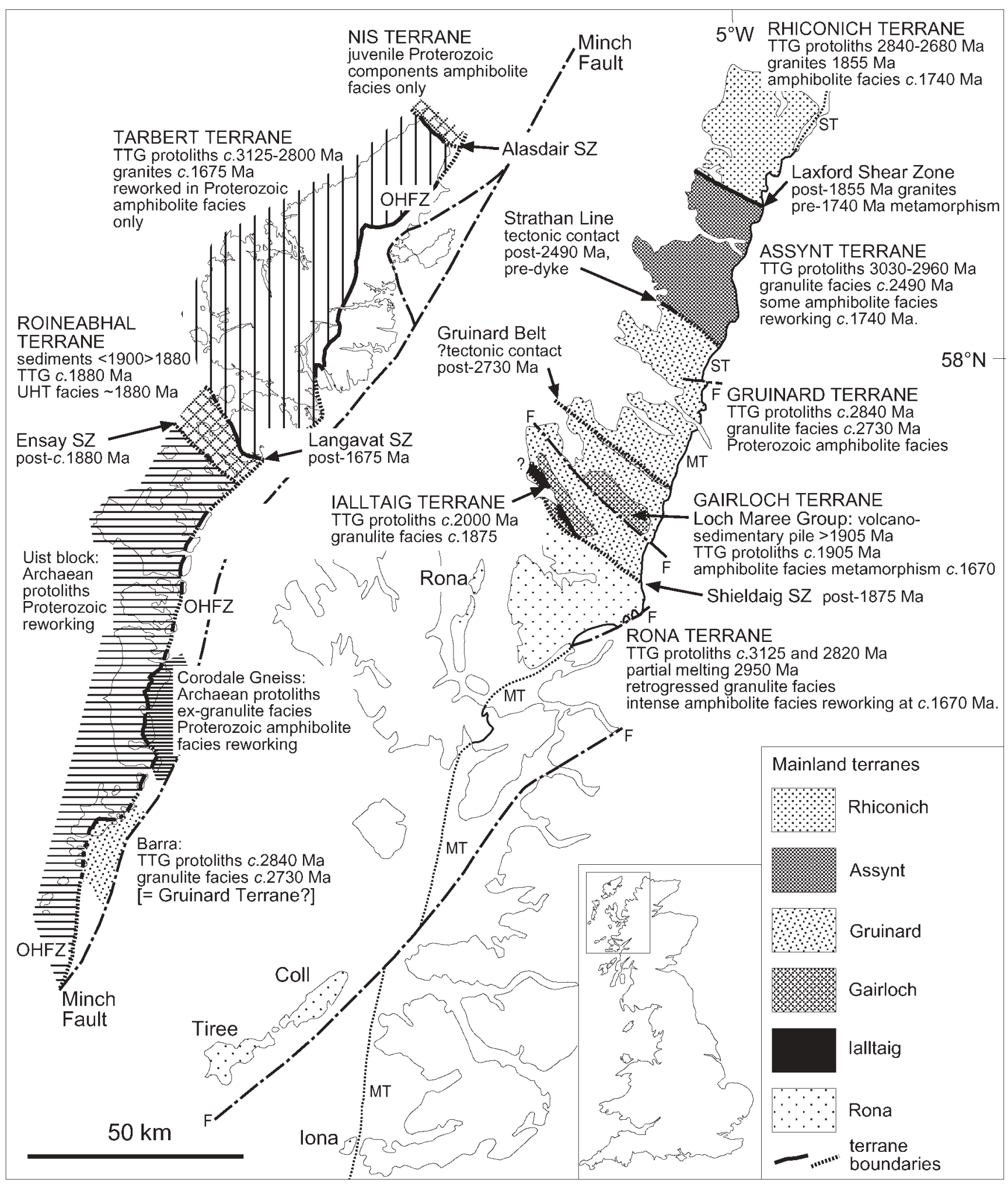

Fig. 1. Sketch map of the Lewisian Gneiss Complex depicting the positions of the proposed component terranes. Inset shows the location of the Complex in NW Scotland. ST, Sole Thrust of the Moine Thrust Zone; MT, Moine Thrust; OHFZ, Outer Hebrides Fault Zone; SZ, shear zone.

respectively. Therefore, at present the dykes can only be used as broad divisors of Archaean and Proterozoic events (e.g. Hall et al. 1985) within the terranes in which they occur, but not for any wider correlations across the complex as a whole.
Loch Maree Group (Bikerman et al. 1975). Originally separated as the Loch Maree series and Gairloch series (Peach \& Horne 1930), the two sequences are now accepted as equivalent (e.g. Park et al. 2001; Park 2002). They comprise mixed mafic and 
felsic volcanic rocks and varied metasedimentary rocks together with lesser calc-alkaline plutonic rocks, metamorphosed at amphibolite facies (Park 1964, 1966; Bikerman et al. 1975; Johnson et al. 1987; Droop et al. 1999; Park et al. 2001). Because the boundaries of the Loch Maree Group are all highly tectonized, there has been considerable debate over what the rocks represent, and their original relationship with the surrounding basement gneisses. Views that they formed pre-Scourian (e.g. Bowes 1969), as a post-Scourian cover sequence (e.g. Peach et al. 1907; Sutton \& Watson 1951; Park 1964), or that they were tectonically emplaced (e.g. Johnson et al. 1987) have been expressed. However, it is now understood that these rocks are Proterozoic, as indicated by $\mathrm{Sm}-\mathrm{Nd}$ isotopic studies (O'Nions et al. 1983) and more recently by zircon $\mathrm{U}-\mathrm{Pb}$ studies (Park et al. 2001; Love 2004). The Loch Maree Group is in tectonic contact with the adjacent gneisses and its interpretation as a Proterozoic arc sequence (Park et al. 2001) is entirely reasonable.

Laxfordian (Sutton \& Watson 1951). This term was defined from the area of Loch Laxford and referred originally to the second major tectonothermal event to have affected the complex. The Laxfordian 'event' was characterized by amphibolite-facies metamorphism and deformation that occurred after the Scourie dykes, affected the Loch Maree Group and reworked much of the basement such that it lost its 'Scourian character' (see Park et al. 1994). The term was also applied to various magmatic and metamorphic events and encompassed events occurring over a considerable time interval, from c. 2200 to $1400 \mathrm{Ma}$ (e.g. Evans \& Park 1965; Park 1970; Bikerman et al. 1975; Park \& Tarney 1987; Park et al. 1994). Laxfordian is redefined here to be used only for the c. $1740 \mathrm{Ma}$ amphibolite-facies metamorphism and deformation found at present in both the Rhiconich and Assynt terranes. Because no juvenile plutonic TTG rocks of this age have yet been recognized on the mainland this event is apparently not subduction related.

\section{Lewisian terranes of the Scottish mainland}

A description of the new and modified terms applicable to the Lewisian terranes follows. The proposed names for six geologically distinct terranes are given (Fig. 1), and events are listed in chronological order. Further subdivisions may be required once more data are obtained on areas less well studied. The current divisions are presented geographically from north to south.

\section{Rhiconich terrane (Friend \& Kinny 2001)}

This name is given to the Precambrian basement rocks occurring in the area between the southern side of Loch Laxford and the north coast between Cape Wrath and Rispond (Fig. 1). Essentially, this terrane corresponds to what was known as the "northern region'. It includes the 'Badnabay zone' of Sutton \& Watson (1951) and is bounded to the south by the Laxford Shear Zone. This terrane has the following components.

Supracrustal rocks. These consist of mafic and metasedimentary enclaves within the TTG gneisses (e.g. Dash 1969; Chowdhary et al. 1971; Chowdhary \& Bowes 1972). These unnamed rocks include quartzites and amphibolites of unknown age.

Inchard gneisses. These include granodioritic TTG suite gneisses with 2840-2800 Ma protolith ages, which form the dominant component of the Rhiconich terrane, and some younger, $c$. $2680 \mathrm{Ma}$ dioritic components (Kinny \& Friend 1997; Friend \&
Kinny 2001).

The above components were affected by an at present undated amphibolite-facies metamorphism accompanied by deformation.

Scourie dyke suite. Members of the suite cross-cut amphibolitefacies fabrics and structures (e.g. Chowdhary \& Bowes 1972), emplaced prior to $1855 \mathrm{Ma}$ (Friend \& Kinny 2001).

Rubha Ruadh granites (Friend \& Kinny 2001; compare the Rubha Ruadh granite gneiss of Sutton \& Watson 1951). These are prominent and widespread, pink-coloured, composite granite-pegmatite sheets that cross-cut amphibolite-facies fabrics, structures and metamorphosed mafic dykes, throughout and exclusive to the Rhiconich terrane. The granites are dated at $c$. $1855 \mathrm{Ma}$.

Laxfordian. This event comprises amphibolite-facies metamorphism and deformation affecting all of the preceding rocks, causing ptygmatic folding and boudinage of the $c$. $1855 \mathrm{Ma}$ Rubha Ruadh Granites. This event is dated at c. $1740 \mathrm{Ma}$ from titanites (Corfu et al. 1994; Kinny \& Friend 1997) that formed parallel to new amphibolite-facies fabrics, and is further constrained by a hornblende Ar/Ar cooling age of c. $1705 \mathrm{Ma}$ (Dallmeyer et al. 2001). This tectonothermal event appears to be the first in common with the Assynt terrane. Hence, the two terranes are interpreted to have been effectively united at or prior to this time, as a result of movements along the Laxford Shear Zone (Friend \& Kinny 2001).

Somerledian. A further overprint at c. $1670 \mathrm{Ma}$, in common with the Assynt terrane, is indicated by $\mathrm{U}-\mathrm{Pb}$ ages of a later generation of titanite and rutile (Corfu et al. 1994). An event at this age appears to be the first shared by the mainland and the Outer Hebrides (Love 2004).

\section{Assynt terrane (Friend \& Kinny 2001)}

This name is given to the Archaean basement rocks in the area between the Laxford Shear Zone in the north and the Strathan Line (Evans \& Lambert 1974), south of Loch Inver (Fig. 1). The northern boundary with the Rhiconich terrane coincides with the northern edge of the 'Foindle zone' of Sutton \& Watson (1951). The main TTG gneisses and their inclusions have been metamorphosed to granulite facies, but in places the rocks have been variably retrogressed by younger events. The history of the terrane prior to the granulite-facies metamorphism is obscure, although the rocks appear to have been subjected to crustal remelting (e.g. Love et al. 2004).

The Assynt terrane includes most of what was termed the 'central region'. However, this newly defined area now specifically excludes the granulite-facies and ex-granulite-facies rocks in the vicinity of Gruinard Bay (e.g. Fowler 1986). Previously these rocks had been correlated with the granulites of the Scourie region (e.g. Rollinson \& Fowler 1987; Corfu et al. 1994, 1998; Park et al. 1994, 2001; Friend \& Kinny 1995). However, Love et al. (2004) have shown that the Gruinard Bay rocks have different protolith ages and metamorphic history and they are now grouped into the separate Gruinard terrane (see below). The Assynt terrane is characterized by the following units and events.

Eanruig supracrustal rocks. These are relics of $\geqslant 2950 \mathrm{Ma}$ supracrustal sequences that are included as rafts and enclaves within the TTG gneisses. Mafic and ultramafic rocks predominate (e.g. Humphries \& Cliff 1982; Whitehouse 1989), although 
a few examples of metasedimentary rocks are known, including aluminous lithologies (Beach 1973; Cartwright \& Barnicoat 1987), calc-silicates (Barooah 1970) and banded iron formation (Barnicoat \& O'Hara 1979). These rocks have been subjected to granulite-facies metamorphism (e.g. Barooah 1970; Beach 1973).

Eddrachillis gneisses. TTG rocks in the Assynt terrane are mostly dioritic to tonalitic in composition, and have protolith ages of 3030-2960 Ma (Friend \& Kinny 1995; Kinny \& Friend 1997).

There is evidence that the gneisses of the Assynt terrane and associated enclaves underwent deformation creating isoclinal folds accompanied by high-grade metamorphism and anatexis in the interval prior to the Badcallian event (see below). Relics of this early history may be represented by trondhjemitic partial melts at Badcall Bay (Love et al. 2004), and recorded by monazites dated at c. $2750 \mathrm{Ma}$ (Zhu et al. 1997).

Badcallian (Park 1970). This is an episode of granulite-facies metamorphism and deformation affecting rocks of the Assynt terrane only. The event is dated at 2490-2480 Ma from mafic supracrustal rocks (e.g. Humphries \& Cliff 1982) and the TTG gneisses (Friend \& Kinny 1995; Kinny \& Friend 1997; Love et al. 2004).

Claisfearn supracrustal rocks (Davies 1975). These were formerly known as the 'Brown Schists' (Peach et al. 1907; Davies 1974). They are metasedimentary rocks occurring immediately south of the Laxford Shear Zone (Fig. 1), east of Tarbert, containing detrital zircons as young as c. 2500 Ma (Love 2004). Unlike the Eanruig supracrustal rocks, these metasedimentary rocks do not appear to have melted and the inference is that their deposition post-dates the Badcallian event.

Inverian (Evans 1965). This was a period of deformation affecting rocks of the Assynt terrane under amphibolite-facies conditions with associated hydration. The Inverian represents events that occurred post-Badcallian and prior to the emplacement of the earliest Scourie dykes, i.e. 2490-2400 Ma. The event also appears to be the first shared with the Gruinard terrane, suggesting that the two were juxtaposed at this time.

Scourie dyke suite. The Assynt terrane is the only one from which any direct age constraints on the suite have been obtained. It includes bronzite-picrite dykes, as exemplified by the $c$. $2400 \mathrm{Ma}$ Beannach dyke (Heaman \& Tarney 1989) and olivine gabbro dykes, as exemplified by the c. 2000 Ma Strathan dyke (Heaman \& Tarney 1989). Other dykes have been dated using $\mathrm{Sm}-\mathrm{Nd}$ whole-rock techniques, e.g. the Badnaban and Rhegreanoch dykes of Waters et al. (1990), which appear to be $c$. 2400 Ma.

Laxfordian. This event, c. $1740 \mathrm{Ma}$ amphibolite-facies metamorphism and deformation, is the first event in common with the Rhiconich terrane (see above). It has been dated from titanite and rutile (Corfu et al. 1994), and further constrained by a rutile age of c. $1700 \mathrm{Ma}$ derived from a Scourie dyke (Heaman \& Tarney 1989).

Somerledian. An amphibolite-facies overprint at c. $1670 \mathrm{Ma}$, in common with the Rhiconich terrane, is indicated by $\mathrm{U}-\mathrm{Pb}$ ages of a later generation of titanite and rutile (Corfu et al. 1994).

\section{Gruinard terrane (Love et al. 2004)}

This name is given to the Archaean basement gneisses south of the Strathan Line to the Gruinard Belt (Fig. 1), a unit of metasedimentary rocks that is correlated with the Loch Maree Group (see Park et al. 2001). Given the structural relations (e.g. Park et al. 2001), these rocks also probably occur further south within the Tollie antiform. The northern part of the Gruinard terrane contains granulite-facies and ex-granulite-facies TTG gneisses, which, together with minor metabasic and metasedimentary units, were previously grouped with the rocks of the Assynt terrane. This terrane is characterized by the following units and events.

Early metabasic components, including the c. $2940 \mathrm{Ma}$ 'main amphibolite suite' of Whitehouse et al. (1996), the c. $2850 \mathrm{Ma}$ hornblendite-metagabbro suite' (Whitehouse et al. 1996) and some minor aluminous metasedimentary units.

Gruinard Bay gneisses. These are TTG suite gneisses with protolith ages of c. $2860 \mathrm{Ma}$ and c. $2825 \mathrm{Ma}$ (Whitehouse et al. 1996, 1997; Corfu et al. 1998; Love et al. 2004).

Inchinaian. The rocks of the Gruinard terrane underwent granulite-facies metamorphism in a pre-Badcallian event at $c$. $2730 \mathrm{Ma}$ (Love et al. 2004), here named the Inchinaian. Associated anatexis led to the introduction of trondhjemitic gneiss sheets and formation of agmatite structures in some areas (e.g. Fowler 1986; Whitehouse 1989; Whitehouse et al. 1996).

Inverian (Evans 1965). This was a period of deformation affecting rocks of the Gruinard terrane under amphibolite-facies conditions with associated hydration. The Inverian represents events that occurred following the Inchinaian event, and prior to the emplacement of the earliest components of the Scourie dyke suite. The event also appears to be the first that is shared with the Assynt terrane, placing it in the time interval 2490-2400 Ma.

Scourie dyke suite. Emplacement of members of the suite occurred in this terrane (e.g. Park \& Tarney 1973; Park et al. 1994).

Further amphibolite-facies metamorphism and deformation was probably in part Somerledian. The timing of these later events in the Gruinard terrane, and which of them are in common with events recorded in the Assynt and terranes to the south, are as yet poorly established.

\section{Gairloch terrane}

This is the proposed name for the Palaeoproterozoic volcanic and metasedimentary rocks and associated intrusive rocks in the district between the Gruinard Belt and the Shieldaig Shear Zone that separates this terrane and the Rona terrane to the south. The Gairloch terrane comprises the following units and events.

Loch Maree Group (Bikerman et al. 1975). These are Palaeoproterozoic volcanic rocks with oceanic basalt and island arc-related chemistries, and associated metasedimentary rocks constrained to be $>1905 \mathrm{Ma}$ old, and interpreted as a juvenile subductionaccretion complex (Park et al. 2001). Detrital zircon ages from the Flowerdale schists span 2200-2000 Ma, suggesting that they are juvenile and relatively locally derived (Whitehouse et al. 1997). 
Ard gneiss (Park 1964). This crops out as c. 1905 Ma intrusive, calc-alkaline granitoid sheets that cut the Loch Maree Group and so limits the age of deposition and of subsequent deformation and metamorphism (Park et al. 2001; Park 2002).

Rocks of the Gairloch terrane have experienced episodes of amphibolite-facies metamorphism and deformation that post-date the emplacement of the Ard gneiss (e.g. Droop et al. 1999). Pegmatites dated at c. $1695 \mathrm{Ma}$ (Park et al. 2001) provide a lower limit to the timing of these events.

\section{Ialltaig terrane}

This is the proposed name for a small, shear-bounded block of Palaeoproterozoic TTG granulite and ex-granulite-facies gneisses tectonically interleaved with the Loch Maree Group in the vicinity of Loch Shieldaig, south of Gairloch. It was previously assumed to be Archaean in age and interpreted as representing the sialic crust against which the Loch Maree Group was accreted (see Park et al. 2001; Park 2002). The terrane consists of the following.

Ialltaig gneiss (Park 1964). This group consists of TTG gneisses, with protoliths dated at c. $2000 \mathrm{Ma}$, that underwent granulitefacies metamorphism at c. 1877 Ma (Love 2004). It also contains a variety of mafic and ultramafic enclaves (Park 1964). That the Loch Maree Group does not record this granulite-facies event is justification for giving the Ialltaig gneiss separate terrane status, despite its small size, as it implies that the two blocks were not juxtaposed until some time after $c .1877 \mathrm{Ma}$.

\section{Rona terrane}

This is a preliminary name for the remaining basement rocks of the Scottish mainland extending south from the Shieldaig Shear Zone bounding the southern side of the Gairloch terrane and through the Torridon area. These rocks were previously included in the 'southern region'. Also included are the Inner Hebridean islands of Raasay, Rona, Coll and Tiree (Fig. 1), where Archaean ages have been indicated (Lyon et al. 1973; Whitehouse \& Robertson 1995). The division of the terrane is still in its early stages, largely because of the extreme post-dyke strain that the rocks have suffered (e.g. Cresswell 1972; Park et al. 1987). The Rona terrane includes the following units and events.

Small screens and pods of largely mafic rock are interpreted as supracrustal rocks intruded by the dominant TTG gneisses (e.g. Cresswell 1972; Bowes et al. 1976).

The earlier TTG suite gneisses include some in the vicinity of Loch Torridon dated at c. $3135 \mathrm{Ma}$ (Love 2004); this makes them the oldest known in the Lewisian Gneiss Complex. Amphibolitefacies metamorphism and anatexis forming granite veins and sheets occurred at c. $2955 \mathrm{Ma}$ (Love 2004).

Later TTG suite gneisses. Some have been dated at c. $2880 \mathrm{Ma}$ (Love 2004). Their relationship to the earlier gneisses is at present unknown. Zircon rims on the $2880 \mathrm{Ma}$ gneisses and a concordia intercept age on an apparently intrusive tonalite of $c$. $2700 \mathrm{Ma}$ suggest that this may be an important period in the early development of the Rona block.

Scourie dyke suite. Mafic dykes, interpreted as members of the Scourie dyke suite, cut the TTG gneisses and early deformational fabrics (e.g. Sutton \& Watson 1951; Cresswell 1972; Wheeler et al. 1987).

Somerledian (?). Amphibolite-facies metamorphism and deformation occurred at $c$. $1670 \mathrm{Ma}$ based on titanite $\mathrm{U}-\mathrm{Pb}$ ages (Love 2004).

\section{Lewisian terranes of the Outer Hebrides}

Compared with the Scottish mainland, the basement rocks of the Outer Hebrides, although lithologically similar, appear to be significantly different in terms of their age relationships (see Friend \& Kinny 2001, and references therein). The chain of islands is divided longitudinally into two portions by the Outer Hebrides Fault Zone (Fig. 1), a zone of complicated, polyphase movement that places granulite-facies and ex-granulite-facies rocks on top of amphibolite-facies gneisses (e.g. Dearnley 1962; Coward 1972; Whitehouse 1993). Whereas the rocks of the footwall (west) show affinities with the geology of Eastern Greenland (Friend \& Kinny 2001), limited data from the hanging wall (east) suggest possible ties with the mainland (Fig. 1). A granulite-facies gneiss from eastern Barra, for example, has yielded similar protolith and metamorphic ages to rocks of the Gruinard terrane. Whether these two regions represent portions of a dismembered block requires further investigation. Currently, the Outer Hebrides exposures are divided into three terranes and one block requiring further subdivision; these are, from north to south, as follows.

\section{Nis terrane (Friend \& Kinny 2001, but note revised spelling)}

Along the north coast of Lewis a thin sliver of apparently entirely Palaeoproterozoic rocks is located to the north of a shear zone up to $c .200 \mathrm{~m}$ wide, named here as the Alasdair shear zone (Fig. 1). The rocks are dominantly plutonic in origin but a small amount of metasedimentary material may be present also (Watson 1969). The rocks are highly deformed and have been metamorphosed under amphibolite-facies conditions. The terrane comprises the following.

Dioritic rocks dated at c. $1870 \mathrm{Ma}$ (Whitehouse \& Bridgwater 2001).

Ness anorthosite (Watson 1969). A disrupted, c. $1860 \mathrm{Ma}$ intrusive gabbro-leucogabbro-anorthosite complex (Whitehouse 1990), which is possibly equivalent to the Roineaval anorthosite of South Harris (see data of Cliff et al. 1983).

\section{Tarbert terrane (Friend \& Kinny 2001)}

This is the name assigned to the amphibolite-facies, Archaean basement gneisses that extend across Lewis from the Alasdair shear zone bounding the Nis terrane southwards to the Langavat-Finsbay shear zone on South Harris (Fig. 1). The terrane is characterized by the following.

Scarp gneisses. This is the proposed name for an older, $c$. $3125 \mathrm{Ma}$ migmatitc TTG gneiss component identified from a locality on the west coast of Harris, opposite the isle of Scarp (Friend \& Kinny 2001).

Carlabhagh gneisses. This is the proposed name, taken from a prominent locality on the central west coast, for the dominant TTG gneisses within the Tarbert terrane. Samples have yielded 
protolith ages of c. 2830 Ma (Pidgeon \& Aftalion 1972; Friend \& Kinny 2001).

Rocks of the Tarbert terrane experienced deformation and metamorphism under amphibolite-facies conditions prior to intrusion of mafic dykes. The Maaruig gabbro is dated at $2140 \pm 38 \mathrm{Ma}$ and has been correlated with emplacement of basic magma into the crust by Cliff et al. (1998).

Harris granite complex (shortened from Uig Hills-Harris Granite Complex (Fettes et al. 1992)). This consists of intrusive granite sheets and neosomes developed at c. $1675 \mathrm{Ma}$ within the TTG gneisses of the Tarbert terrane during an episode of amphibolite-facies metamorphism (Friend \& Kinny 2001). This event is absent from the adjoining Roineabhal terrane to the south.

Cooling ages of $1300 \mathrm{Ma}$ have been obtained by $\mathrm{Rb}-\mathrm{Sr}$ dating of biotites (Cliff \& Rex 1989).

\section{Roineabhal terrane (Friend \& Kinny 2001)}

This name is given to the juvenile, Palaeoproterozoic, volcanosedimentary arc rocks on South Harris that form a discrete block sandwiched between the Archaean Tarbert terrane to the north and Uist/Barra block to the south (Fig. 1). The bounding shear zones are the Langavat-Finsbay shear zone to the north and the Ensay shear zone to the south. The terrane comprises the following.

Langavat and Leverburgh belts (Dearnley 1962). Sequences of pelitic, psammitic and calcareous metasediments deposited prior to c. $1880 \mathrm{Ma}$ (Friend \& Kinny 2001; Whitehouse \& Bridgwater 2001), that lie respectively north and south of the South Harris Igneous Complex and into which components of the complex were emplaced.

South Harris igneous complex (Dearnley 1963). This is a composite intrusive plutonic complex of which the main components are:

(1) Roneval anorthosite (Davidson 1943), a basic complex that intrudes the Langavat and Leverburgh belts (e.g. Davidson 1943; Dearnley 1963; Witty 1975; Friend \& Lailey 1986) and so provides a minimum age for their deposition;

(2) Scarista tonalite (Whitehouse \& Bridgwater 2001), a pluton dated at c. $1880 \mathrm{Ma}$.

UHT (Baba 1999) granulite-facies metamorphism at $c$. $1870 \mathrm{Ma}$ (e.g. Cliff et al. 1983; Whitehouse \& Bridgwater 2001) affected the whole terrane and caused extensive anatexis in the Leverburgh Belt (Friend \& Kinny 2001).

Subsequent events include polyphase deformation and retrogressive amphibolite-facies metamorphism and pegmatite emplacement (e.g. Chiapaval). Some of this must be associated with juxtaposition of the Tarbert terrane, which occurred after $1675 \mathrm{Ma}$, the age of the Harris Granite Complex and associated metamorphism. It is also possible that some metamorphism is as young as Grenvillian and related to movements on the Outer Hebrides Fault Zone (e.g. Cliff \& Rex 1989; Imber et al. 2002), as indicated by c. $1100 \mathrm{Ma}$ biotite $\mathrm{Rb}-\mathrm{Sr}$ cooling ages.

Uist/Barra block. This is the preliminary name assigned to the at present undifferentiated but predominantly Archaean basement gneisses of the Outer Hebrides that extend south of the Ensay shear zone to the islands south of Barra (Fig. 1), including rocks on both sides of the Outer Hebrides Fault Zone. The Uist/Barra block comprises the following.
Deformed and metamorphosed Archaean TTG protoliths. These include granulite-facies TTG gneisses on Barra with a protolith age of c. $2825 \mathrm{Ma}$ and amphibolite-facies gneisses on Berneray and South Uist with protolith ages of c. 2770-2750 Ma (Whitehouse \& Bridgwater 2001; Love 2004).

Corodale gneiss (Coward 1972). This consists of remnants of an Archaean, partially layered gabbro-diorite complex (Whitehouse 1993), occurring in the hanging wall of the Outer Hebrides Fault Zone on South Uist.

Granulite-facies metamorphism affects hanging-wall rocks on South Uist and on Barra, where it has been tentatively dated at $c$. 2730 Ma (Love 2004).

Several generations of mafic dykes occur (e.g. Dearnley \& Dunning 1968).

The rocks have undergone deformation and amphibolite-facies metamorphism with anatexis in some places. Granitic neosomes in the footwall gneisses on South Uist have been dated at $c$. 1700 Ma (Love 2004).

\section{Terrane boundaries and assembly}

The terrane boundaries identified here are not new, but are wellknown structures that were interpreted very differently in the past. The precise position of the junction of the Assynt and Rhiconich terranes in the Laxford Shear Zone, for example, was in fact accurately identified by Watson in the original mapping (Sutton \& Watson 1951).

The terranes recognized here fall into two groups, those representing pieces of reworked Archaean continental crust and those that have the geochemistry and ages of the Palaeoprotozoic juvenile arcs: Gairloch (Park et al. 2001), Roineabhal (Baba 1999) and Nis (Whitehouse 1990). However, there are still problems in relating these latter to the Archaean blocks on either side, as no subduction-related products have been found in the adjacent terranes. Only basic dykes are present, which may be a common witness to an earlier extension event. The identified boundaries thus separate diverse packages of lithologically and geochronologically distinctive rocks that comply with the definition of Coney et al. (1980) for terranes. The terranes vary in size considerably from the Ialltaig terrane, which comprises a slice of granulite-facies, Palaeoproterozoic crust, caught up in lowergrade arc-like rocks. The suggestion is therefore that these represent fragments of once larger crustal blocks. The evidence suggests that the boundaries between the terranes, as observed at present, appear to have developed in a transcurrent setting. These boundaries occupy relatively narrow zones but, at the present resolution, it is not understood how much imbrication of units there might be; for example, at the Strathan Line (Evans \& Lambert 1974). Here a series of southerly dipping, top-to-thenorth directed shears bring the Gruinard terrane over the Assynt terrane and plausibly could cause fine-scale duplication. However, the distance over which this occurs, $c .500 \mathrm{~m}$, is considered a detail, rather than the principle, which is being established here.

Regardless of uncertainties in the tectonic settings, it is clear from the new geochronology that the complex was assembled in a stepwise fashion by a series of amalgamation events in the Proterozoic. On the mainland, further dating of minerals formed during some of the later amphibolite-facies events, pegmatites and minor intrusions will be important in further establishing 
when the terranes underwent common events and hence give a better understanding of the sequence of terrane assembly. On the Outer Hebrides, another important although difficult task is to establish in more detail the relative ages of the gneisses above and below the Outer Hebrides Fault Zone on South Uist and Barra.

\section{Conclusions}

The proposed new nomenclature outlined above is a fresh approach based upon two lines of evidence. It builds on the vast array of published lithological, petrological and structural data to which is added an extensive, robust, modern geochronological database, and addresses the continuing nomenclature problem without recourse to the old concepts of crustal evolution for the region. The new concept is based on the recognition that each terrane has its own history until juxtaposed with another terrane, after which they have a common history. Perhaps the pioneers of Lewisian geology foresaw this development when they stated: 'The Lewisian gneiss is not a geological formation in the ordinary sense of the word. Even if we exclude from it the later dykes and sills, there still remains a petrographical complex which future research will probably separate into its component parts' (Peach et al. 1907). Once more of the detailed history of each terrane is known, any new events identified can be assigned to their rightful place within this new overall framework, and further subdivisions can be introduced if required, as will probably be the case for the comparatively poorly understood Rona terrane and Uist/Barra block, where post-dyke reworking has been very intense and so renders establishment of protolith ages difficult.

Importantly, the Lewisian Gneiss Complex now appears to comprise two distinctly different longitudinal segments of gneissic crust, separated by the Outer Hebrides Fault Zone. East of the Outer Hebrides Fault Zone the rocks preserve Neoproterozoic cooling ages (Cliff \& Rex 1989) whereas the mainland apparently does not. It is important to try to establish when and how this important boundary evolved because it could represent the most easterly unmodified margin of the former Laurentian continent (see Friend \& Kinny 2001).

P.D.K. and G.J.L. acknowledge continuing support from the Tectonics Special Research Centre. R. G. Park is thanked for many long discussions dealing with problems of general Lewisian Gneiss Complex evolution and its nomenclature. The many detailed comments of D. R. Bowes, who fundamentally disagrees with most of what is presented here, were extremely helpful in assisting us to clarify some of our ideas. Additionally, M. B. Fowler, K. Goodenough and R. A. Strachan made many helpful comments on early drafts. The reviewers, S. Daly, J. Mendum and R. G. Park, are thanked for their constructive and detailed comments.

\section{Appendix: Abandoned terminology}

The following terms are now considered to be obsolete. With the exception of Scourian they are no longer in common use. This compilation includes all gneissic units referred to in stratigraphic terms as 'groups' or in petrographic terms as 'assemblages', and all names that group together rocks now known to have separate origins and histories.

Brown Schists (Peach et al. 1907; Davies 1974). Term used to describe the supracrustal rocks in the vicinity of Tarbert and Claisfearn. Davies (1975) inferred that the supracrustal rocks were all of the same age and coined the term Claisfearn supracrustal rocks for them. This term is now redefined above.
Clach Boga Gneisses (Davies 1975). Term used for younger gneisses in the vicinity of Badcall Bay that were supposedly intrusive into the older Uamhaig Gneisses.

Fundamental complex (Peach et al. 1907). An early name for the complex.

Gairloch assemblage (Holland \& Lambert 1973). Old term for the amphibolite-facies rocks within the Proterozoic rocks in the Loch Maree Group. As these rocks have undergone polyphase metamorphism (Droop et al. 1999) the term is ambiguous.

Gruinard assemblage (Holland \& Lambert 1973). Descriptive term for the gneisses at Gruinard Bay and on Rhum.

Harris Migmatite Complex (Myers 1971). Term applied to the irregular bodies and sheets of granite that cut the gneisses in the northern part of South Harris.

Inver assemblage (Holland \& Lambert 1973). Term used for retrogressed granulite-facies rocks in vicinity of Lochinver. Groups granulites formed in different events and, as well as the main retrogression event, includes retrogression at other times.

Kernsary assemblage (Holland \& Lambert 1973). Supposedly gradational into the Gruinard assemblage (see above).

Kylesku group (Khoury 1968). Term used for the gneisses in the vicinity of Kylesku that were supposed to represent supracrustal rocks.

Laxford assemblage (Holland \& Lambert 1973). Term used for the gneisses north of the 'Ben Stack Line', in part equivalent to the Rhiconich group of Dash (1969).

Laxfordian granite sheets (Sutton \& Watson 1951). Term used for the granitic gneiss sheets occurring north of the 'Ben Stack Line' (e.g. Beach et al. 1974) and used to correlate across The Minch onto Lewis and Harris (e.g. Dearnley 1962). As the granite sheets north of Loch Laxford are c. 1860 Ma old (Kinny \& Friend 1997), they are not 'Laxfordian' in terms of the new definition, but represent an earlier event. Similarly, those on the Outer Hebrides are c. $1670 \mathrm{Ma}$ and equally fall outside the new definition. In this paper these granites are referred to as the Rubha Ruadh Granites (mainland) and the Harris Granites Complex (Outer Hebrides).

Rhiconich group (Dash 1969). Name given to the main group of gneisses of the northern region, mistakenly interpreted as supracrustal rocks.

Scourian (Sutton \& Watson 1951). This term has, rather confusingly, been used for gneisses, metamorphism and time (Evans \& Lambert 1974; Bowes 1978; Park et al. 1994; Holland Holland \& Lambert 1995) and so has no clear definition (e.g. Park 1970). In the light of the new geochronology for the granulite-facies events, this term cannot easily be redefined and so is abandoned.

Scourie assemblage (Holland \& Lambert 1973). Term used for garnet-pyroxene gneisses in the vicinity of Scourie and Lochinver, grouping together mineral assemblages that formed from different protoliths and different metamorphic events under different conditions (e.g. Fowler 1986).

Shios Dykes (Davies 1975). Term used to describe some mafic and ultramafic bodies interpreted as broken-up dykes associated with the Uamhaig Gneisses in the vicinity of Badcall Bay.

South Harris Injection Complex (Dearnley 1963). Term applied to the irregular bodies and sheets of granite that cut the gneisses in northern South Harris.

Southern Laxford assemblage (Holland \& Lambert 1973). Term used for the gneisses SW of the 'Gairloch boundary fault' (now the Shieldaig Shear Zone).

Uamhaig Gneisses (Davies 1975). Term used for the older gneisses in the vicinity of Badcall Bay; essentially equivalent to the Scourie gneisses. (Chapman \& Moorball 1977). 


\section{References}

BABA, S. 1999. Sapphirine-bearing orthopyroxene-kyanite/sillimanite granulites from South Harris, NW Scotland: evidence for Proterozoic UHT metamorphism in the Lewisian. Contributions to Mineralogy and Petrology, 136, 33-47.

BARnicoAT, A.C. \& O'HARA, M.J. 1979. High temperature pyroxenes from an ironstone at Scourie. Mineralogical Magazine, 43, 371-375.

BARoOAH, B.C. 1970. Significance of calc-silicate rocks and meta-arkose in the Lewisian complex south-east of Scourie. Scottish Journal of Geology, 6, $221-225$.

BEACH, A. 1973. The mineralogy of high temperature shear zones at Scourie. Journal of Petrology, 14, 231-248.

Beach, A., Coward, M.P. \& Graham, R.C. 1974. An interpretation of the structural evolution of the Laxford Front, north-west Scotland. Scottish Journal of Geology, 9, 297-308.

Bikerman, M., Bowes, D.R. \& VAN Breemen, O. 1975. Rb-Sr whole rock isotopic studies of Lewisian metasediments and gneisses in the Loch Maree region, Ross-shire. Journal of the Geological Society, London, 131, $237-254$

Bowes, D.R. 1969. The Lewisian of Northwest Highlands of Scotland. In: KAY, M. (ed.) North Atlantic Geology and Continental Drift-a Symposium. American Association of Petroleum Geologists, Memoirs, 12, 575-594.

Bowes, D.R. 1971. Lewisian chronology. Scottish Journal of Geology, 7, 179-182.

Bowes, D.R. 1978. Shield formation in early Precambrian times: the Lewisian complex. Geological Journal, Special Issue, 10, 39-80.

Bowes, D.R., Barooah, B.C. \& KHOURY, S.G. 1971. Original nature of Archaean rocks of North-West Scotland. Special Publication of the Geological Society, Australia, 3, 77-92.

Bowes, D.R., Hopgood, A.M. \& Pidgeon, R.T. 1976. Source ages of zircons in an Archaean quartzite, Rona, Inner Hebrides, Scotland. Geological Magazine, 113, 545-552.

Bridgwater, D., Watson, J. \& Windley, B.F. 1973. The Archaean craton of the North Atlantic region. Philosophical Transactions of the Royal Society of London, Series A, 273, 493-512.

Burton, K.W., Capmas, F., Birck, J.-L., Allègre, C.J. \& Cohen, A.S. 2000. Resolving crystallisation ages of Archaean mafic-ultramafic rocks using the $\mathrm{Re}-\mathrm{Os}$ isotope system. Earth and Planetary Science Letters, 179, 453-467.

Chapman, H.J. \& Moorbath, S. 1977. Lead isotope measurements from the oldest recognised Lewisian gneisses of north-west Scotland. Nature, 268, 41-42.

CARTwright, I. \& BARnicoat, A.C. 1987. Petrology of Scourian supracrustal rocks and orthogneisses from Stoer, NW Scotland: implications for the geological evolution of the Lewisian complex. In: PARK, R.G. \& TARnEY, J. (eds) Evolution of the Lewisian and Comparable Precambrian High Grade Terrains. Geological Society, London, Special Publications, 27, 93-107.

Chowdhary, P.K. \& Bowes, D.R. 1972. Structure of Lewisian rocks between Loch Inchard and Loch Laxford, Sutherland, Scotland. Krystalinikum, 9, $21-51$.

Chowdhary, P.K., Dash, B. \& Findlay, D. 1971. Metasediments in the Rhiconich group of the Lewisian between Loch Laxford and Durness, Sutherland. Scottish Journal of Geology, 1, 295-299.

Cliff, R.A. \& REX, D.C. 1989. Evidence for a 'Grenville' event in the Lewisian of the northern Outer Isles. Journal of the Geological Society, London, 146, 921-924.

Cliff, R.A., Grey, C.M. \& Huhma, H. 1983. A Sm-Nd isotopic study of the South Harris Igneous Complex, the Outer Hebrides. Contributions to Mineralogy and Petrology, 82, 91-98.

Cliff, R.A., ReX, D. \& Guise, P.G. 1998. Geochronological studies of Proterozoic crustal evolution in the northern Outer Hebrides. Precambrian Research, 91, $401-418$.

Coney, P.J., Jones, D.L. \& Monger, J.W.H. 1980. Cordilleran suspect terranes. Nature, 288, 329-333.

Corfu, F., Heaman, L.M. \& Rogers, G. 1994. Polymetamorphic evolution of the Lewisian complex, NW Scotland, as recorded by $\mathrm{U}-\mathrm{Pb}$ isotopic compositions of zircon, titanite and rutile. Contributions to Mineralogy and Petrology, 117, $215-228$.

Corfu, F., Crane, A., Moser, D. \& Rogers, G. 1998. U-Pb zircon systematics at Gruinard Bay, northwest Scotland: implications for the early orogenic evolution of the Lewisian complex. Contributions to Mineralogy and Petrology, 133, 319-345.

Coward, M.P. 1972. The Eastern Gneisses of South Uist. Scottish Journal of Geology, 8, 1-12.

CowARD, M.P. 1973. Heterogeneous deformation in the development of the Laxfordian complex of South Uist, Outer Hebrides. Journal of the Geological Society, London, 129, 137-160.

Crane, A. 1978. Correlation of metamorphic fabrics and the age of Lewisian metasediments near Loch Maree. Scottish Journal of Geology, 14, 225-246.

Cresswell, D. 1972. The structural development of the Lewisian rocks on the north shore of Loch Torridon, Ross-shire. Scottish Journal of Geology, 8, 293-308.
Dallmeyer, R.D., Strachan, R.A., Rogers, G., Watt, G.R. \& Friend, C.R.L. 2001. Dating deformation and cooling in the Caledonian thrust nappes of north Sutherland, Scotland: insights from ${ }^{40} \mathrm{Ar} /{ }^{39} \mathrm{Ar}$ and $\mathrm{Rb}-\mathrm{Sr}$ chronology. Journal of the Geological Society, London, 158, 501-512.

DASH, B. 1969. Structure of the Lewisian rocks between Strath Dionard and Rhiconich, Sutherland. Scottish Journal of Geology, 5, 347-374.

DAvidson, C.F. 1943. The Archaean rocks of the Rodil district, South Harris, Outer Hebrides. Transactions of the Royal Society of Edinburgh, 61, 71-112.

DAvies, F.B. 1974. A layered basic complex in the Lewisian south of Loch Laxford, Sutherland. Journal of the Geological Society, London, 130, 279-284.

DAviES, F.B. 1975. Origin and ancient history of gneisses older than 2,800 Myr in Lewisian Complex. Nature, 258, 589-591.

Davies, F.B. 1977. Archaean evolution of the Lewisian complex of Gruinard Bay. Scottish Journal of Geology, 13, 189-196.

Davies, F.B. \& WATson, J.V. 1977. Early basic bodies in the type Laxfordian complex, NW Scotland and their bearing on its origin. Journal of the Geological Society, London, 133, 123-131.

DeARnLEy, R. 1962. An outline of the Lewisian complex of the Outer Hebrides in relation to that of the Scottish mainland. Quarterly Journal of the Geological Society of London, 118, 143-176.

Dearnley, R. 1963. The Lewisian complex of South Harris. Quarterly Journal of the Geological Society of London, 119, 243-312.

Dearnley, R. \& Dunning, F.W. 1968. Metamorphosed and deformed pegmatites and basic dykes in the Lewisian complex of the Outer Hebrides and their geological significance. Quarterly Journal of the Geological Society of London, 123, 353-378.

Droop, G.T.R., Fernandes, L.A.D. \& SHaw, S. 1999. Laxfordian metamorphic conditions of the Palaeproterozoic Loch Maree Group, Lewisian Complex, NW Scotland. Scottish Journal of Geology, 35, 31-50.

Evans, C.R. 1965. Geochronology of the Lewisian basement near Lochinver, Sutherland. Nature, 207, 54-56.

Evans, C.R. \& Lambert, R.ST.J. 1974. The Lewisian of Lochinver, Sutherland; the type area for the Inverian metamorphism. Journal of the Geological Society, London, 130, 125-150.

Evans, C.R. \& PARK, R.G. 1965. Potassium-argon age determinations from the Lewisian of Gairloch, Ross-shire, Scotland. Nature, 205, 350-352.

Evans, C.R. \& TARney, J. 1964. Isotopic ages of Assynt dykes. Nature, 204, 638-641.

Fettes, D. \& Mendum, J.R. 1987. The evolution of the Lewisian complex in the Outer Hebrides. In: PARK, R.G. \& TARNEY, J. (eds) Evolution of the Lewisian and Comparable Precambrian High Grade Terrains. Geological Society, London, Special Publications, 27, 27-44.

Fettes, D., Mendum, J.R., Smith, D.I. \& Watson, J.V. 1992. Geology of Outer Hebrides. Memoir of the British Geological Survey.

FIELD, D. 1978. Granulites at Gruinard Bay. Scottish Journal of Geology, 14, $359-361$.

FowLER, M.B. 1986. Large-ion lithophile element characteristics of an amphibolite to granulite facies transition at Gruinard Bay, North-west Scotland. Journal of Metamorphic Geology, 4, 345-359.

Friend, C.R.L. \& KinNY, P.D. 1995. New evidence for the protolith ages of Lewisian granulites, northwest Scotland. Geology, 23, 1027-1030.

Friend, C.R.L. \& KINNY, P.D. 2001. A reappraisal of the Lewisian Gneiss Complex: geochronological evidence for its tectonic assembly from disparate terranes in the Proterozoic. Contributions to Mineralogy and Petrology, 142, $198-218$.

Friend, C.R.L. \& Lailey, M. 1986. Evidence for early structures in the South Harris anorthosite, Outer Hebrides. Scottish Journal of Geology, 23, 407-411.

Friend, C.R.L., Nutman, A.P. \& McGregor, V.R. 1988. Late Archaean terrane accretion in the Godthåb region, southern West Greenland. Nature, 335, $535-538$.

Friend, C.R.L., Nutman, A.P., BaAdsgaArd, H., Kinny, P.D. \& McGregor, V.R. 1996. Timing of late Archaean terrane assembly, crustal thickening and granite emplacement in the Nuuk region, southern West Greenland. Earth and Planetary Science Letters, 142, 353-365.

Giletti, B.J., Moorbath, S. \& Lambert, R.St.J. 1961. A geochronological study of the metamorphic complexes of the Scottish Highlands. Quarterly Journal of the Geological Society of London, 117, 233-272.

Gillen, C. 1975. Structural and metamorphic history of the Lewisian gneiss around Loch Laxford, Sutherland, Scotland. Krystalinikum, 11, 63-85.

Hall, R.P., Hughes, D.J. \& Friend, C.R.L. 1985. Geochemical evolution and unusual pyroxene chemistry of the MD tholeiitic dyke swarm from the Archaean craton of southern West Greenland. Journal of Petrology, 26, $253-282$.

Hamilton, P.J., Evensen, N.M. \& O'Nions, R.K. 1979. Sm-Nd systematics of Lewisian gneisses: implications for the origin of granulites. Nature, 277, 25-28.

Heaman, L.M. \& Tarney, J. 1989. U-Pb baddeleyite ages for the Scourie dyke 
swarm, Scotland: evidence for two distinct intrusion events. Nature, 340, $705-708$.

Holland, J.G. \& Lambert, R.St.J. 1973. Comparative major element geochemistry of the Lewisian of the mainland of Scotland. In: PARK, R.G. \& TARNEY, J. (eds) The Early Precambrian of Scotland and Related Rocks of Greenland. University of Keele, Newcastle under Lyme, 51-62.

Holland, J.G. \& LamberT, R.ST.J. 1995. The geochemistry and geochronology of the gneisses and pegmatites of the Tollie antiform in the Lewisian complex of northwestern Scotland. Canadian Journal of Earth Sciences, 32, 496-507.

Humphries, F. \& Cliff, R.A. 1982. Sm-Nd dating and cooling history of Scourian granulites. Nature, 295, 515-517.

Imber, J., Strachan, R.A., Holdsworth, R.E. \& Butler, C.A. 2002. Sm-Nd dating and cooling history of Scourian granulites. Geological Magazine, 139, 609-619.

Johnson, Y., PARK, R.G. \& Winchester, J. 1987. Geochemistry, petrogenesis and tectonic significance of the Early Proterozoic Loch Maree amphibolites. In: Pharaoh, T., Beckinsale, R.D. \& Rickards, D.T. (eds) Geochemistry and Mineralization of Proterozoic Volcanic Suites. Geological Society, London, Special Publications, 33, 255-269.

KHourY, S.G. 1968. Structural analysis of complex fold belts in the Lewisian north of Kylesku, Sutherland, Scotland. Scottish Journal of Geology, 4, $109-120$.

KINNY, P.D. \& FRIEND, C.R.L. 1997. U-Pb isotopic evidence for the accretion of different crustal blocks to form the Lewisian Complex of Northwest Scotland. Contributions to Mineralogy and Petrology, 129, 326-340.

LISLE, R.J. 1977. The evaluation of Laxfordian deformation in the Carloway area, Isle of Lewis, Scotland. Tectonophysics, 42, 183-208.

Love, G.J. 2004. The origins and accretionary development of the Lewisian Gneiss Complex of Northwest Scotland: constraints from in situ $\mathrm{U}-\mathrm{Pb}$ and $\mathrm{Hf}$ isotopic analysis of accessory minerals. $\mathrm{PhD}$ thesis, Curtin University of Technology, Perth, W.A.

Love, G.J., Kinny, P.D. \& Friend, C.R.L. 2004. Timing of magmatism and metamorphism in the Gruinard Bay area of the Lewisian Gneiss Complex: comparisons with the Assynt Terrane and implications for terrane accretion. Contributions to Mineralogy and Petrology, 146, 620-636.

Lyon, T.D.B. \& Bowes, D.R. 1977. Rb-Sr, U-Pb, and K-Ar isotopic study of the Lewisian complex between Durness and Loch Laxford, Scotland. Krystalinikum, 13, 53-72.

Lyon, T.D.B., Pidgeon, R.T., Bowes, D.R. \& Hopgood, A.R. 1973. Geochronological investigation of the quartzofeldspathic rocks of the Lewisian of Rona, Inner Hebrides. Journal of the Geological Society, London, 129, 389-404.

McGregor, V.R. 1973. The early Precambrian gneisses of the Godthåb district, West Greenland. Philosophical Transactions of the Royal Society of London, Series A, 273, 343-358.

Moorbath, S. 1977. Ages, isotopes and the evolution of Precambrian continental crust. Chemical Geology, 20, 151-187.

Moorbath, S. \& Park, R.G. 1971. The Lewisian chronology of the southern region of the Scottish mainland. Scottish Journal of Geology, 8, 51-74.

Moorbath, S., Welke, H. \& Gale, N.H. 1969. The significance of lead isotope studies in ancient high-grade metamorphic basement complexes, as exemplified by the Lewisian rocks of northwest Scotland. Earth and Planetary Science Letters, 6, 245-256.

Moorbath, S., Powell, J.L. \& Taylor, P.N. 1975. Isotopic evidence for the age and origin of the 'grey gneiss' complex of the southern Outer Hebrides. Journal of the Geological Society, London, 131, 213-222.

Myers, J.S. 1971. The late Laxfordian granite-migmatite complex of Western Harris, Outer Hebrides. Scottish Journal of Geology, 7, 254-284.

Nutman, A.P., Bennett, V.C., Kinny, P.D. \& Price, R. 1993. Large-scale crustal structure of the northwest Yilgarn Craton, Western Australia: evidence from $\mathrm{Nd}$ isotope data and SHRIMP $\mathrm{U}-\mathrm{Pb}$ zircon geochronology. Tectonics, 12, 971-981.

O'Nions, R.K., Hamilton, P.J. \& Hooker, P.J. 1983. A Nd isotope investigation of sediments related to crustal development in the British Isles. Earth and Planetary Science Letters, 63, 229-240.

PARK, R.G. 1964. The structural history of the Lewisian rocks of Gairloch, Wester Ross, Scotland. Quarterly Journal of the Geological Society of London, 120, 397-433.

PARK, R.G. 1966. Nature and origin of Lewisian basic rocks at Gairloch, Wester Ross. Scottish Journal of Geology, 2, 179-199.

PARK, R.G. 1970. Observations on Lewisian chronology. Scottish Journal of Geology, 6, 379-399.

PARK, R.G. 1971. Lewisian chronology. Scottish Journal of Geology, 7, 184-187.

PARK, R.G. 2002. Geology of the Gairloch Area. Geological Society, London, Memoirs, 26.

PARK, R.G. \& TARney, J. 1973. The Early Precambrian of Scotland and Related Rocks of Greenland. University of Keele, Newcastle under Lyme.

PARK, R.G. \& TARnEY, J. 1987. The Lewisian complex: a typical Precambrian high-grade terrain? In: PARK, R.G. \& TARneY, J. (eds) Evolution of the
Lewisian and Comparable Precambrian High Grade Terrains. Geological Society, London, Special Publications, 27, 13-25.

Park, R.G., Crane, A. \& Naimatullah, M. 1987. Early Proterozoic structure and kinematic evolution of the southern mainland Lewisian. In: PARK, R.G. \& TARney, J. (eds) Evolution of the Lewisian and Comparable Precambrian High Grade Terrains. Geological Society, London, Special Publications, 27, $139-151$.

Park, R.G., Cliff, R.A., Fettes, D.J. \& Stewart, A.D. 1994. Precambrian rocks in northwest Scotland west of the Moine Thrust: the Lewisian Complex and the Torridonian. In: Gibbons, W. \& Harris, A.L. (eds) A Revised Correlation of Precambrian Rocks in the British Isles. Geological Society, London, Special Reports, 22, 6-22.

Park, R.G., TARney, J. \& Connelly, J.N. 2001. The Loch Maree Group: Palaeoproterozoic subduction-accretion complex in the Lewisian of NW Scotland. Precambrian Research, 105, 205-226.

Peach, B.N. \& Horne, J. 1930. Chapters on the Geology of Scotland. Publisher, London.

Peach, B.N., Horne, J., Gunn, W., Clough, C.T., Hinxman, L.W. \& Teall, J.J.H. 1907. The Geological Structure of the North West Highlands of Scotland. Memoir of the Geological Survey.

Pidgeon, R.T. \& Aftalion, M. 1972. The geochronological significance of discordant $\mathrm{U}-\mathrm{Pb}$ ages of oval-shaped zircons from a Lewisian gneiss from Harris, Outer Hebrides. Earth and Planetary Science Letters, 17, 268-274.

Pidgeon, R.T. \& Bowes, D.R. 1972. Zircon U-Pb ages of granulites from the Central Region of the Lewisian, northwestern Scotland. Geological Magazine, 109, 247-258.

Rollinson, H.R. 1996. Tonalite-trondhjemite-granodiorite magmatism and genesis of Lewisian crust during the Archaean. In: BREWER, T.S. (ed.) Precambrian Crustal Evolution in the North Atlantic Region. Geological Society, London, Special Publications, 112, 25-42.

Rollinson, H.R. \& Fowler, M.B. 1987. The magmatic evolution of the Scourian complex at Gruinard Bay. In: PARK, R.G. \& TARney, J. (eds) Evolution of the Lewisian and Comparable Precambrian High Grade Terrains. Geological Society, London, Special Publications, 27, 57-71.

Rollinson, H.R. \& Windley, B.F. 1980. An Archaean granulite-grade TonaliteTrondhjemite-Granite suite from Scourie, NW Scotland: geochemistry and origin. Contributions to Mineralogy and Petrology, 72, 265-281.

Sheraton, J.W., Skinner, A.C. \& Tarney, J. 1973a. The geochemistry of the Scourian gneisses of the Assynt district. In: PARK, R.G. \& TARney, J. (eds) The Early Precambrian of Scotland and Related Rocks of Greenland. University of Keele, Newcastle under Lyme, 13-30.

Sheraton, J.W., Tarney, J., Wheatley, T.J. \& Wright, A.E. 1973b. The structural history of the Assynt district. In: PARK, R.G. \& TARneY, J. (eds) The Early Precambrian of Scotland and Related Rocks of Greenland. University of Keele, Newcastle under Lyme, 31-43.

Sutton, J. \& Watson, J. 1951. The pre-Torridonian metamorphic history of the Loch Torridon and Scourie areas in the North-West Highlands and its bearing on the chronological classification of the Lewisian. Quarterly Journal of the Geological Society of London, 106, 241-296.

Sutton, J. \& Watson, J. 1962. Further observations on the margin of the Laxfordian complex of the Lewisian near Loch Laxford, Sutherland. Transactions of the Royal Society of Edinburgh, 65, 89-106.

Sutton, J. \& WAtson, J. 1969. Scourian-Laxfordian relationships in the Lewisian of North-West Scotland. In: Wynne-Edwards, H.R. ET AL. (eds) Age Relations in High-grade Metamorphic Terrains. Special Paper of the Geological Association of Canada, 5, 119-128.

TARnEY, J. 1987. The Scourie dyke suite and the nature of the Inverian event in Assynt. In: PARK, R.G. \& TARney, J. (eds) Evolution of the Lewisian and Comparable Precambrian High Grade Terrains. Geological Society, London, Special Publications, 27, 105-118.

TARney, J. \& Weaver, B.L. 1987. Geochemistry of the Scourian complex: petrogenesis and tectonic models. In: PARK, R.G. \& TARNEY, J. (eds) Evolution of the Lewisian and Comparable Precambrian High Grade Terrains. Geological Society, London, Special Publications, 27, 45-56.

Waters, F., Cohen, A.S., O’Nions, R.K. \& O'Hara, M.J. 1990. Development of Archaean lithosphere deduced from chronology and isotope chemistry of Scourie Dykes. Earth and Planetary Science Letters, 97, 241-255.

Watson, J.V. 1969. The Precambrian gneiss complex of Ness, Lewis, in relation to the effects of Laxfordian regeneration. Scottish Journal of Geology, 5, $269-285$.

Wheeler, J., Windley, B.F. \& Davies, F.B. 1987. Internal evolution of the major Precambrian shear belt at Torridon, NW Scotland. In: PARK, R.G. \& TARNEY, J. (eds) Evolution of the Lewisian and Comparable Precambrian High Grade Terrains. Geological Society, London, Special Publications, 27, 153-163.

Whitehouse, M.J. 1988. Granulite facies Nd-isotopic homogenisation in the Lewisian complex of northwest Scotland. Nature, 331, 705-707.

Whitehouse, M.J. 1989. Sm-Nd evidence for diachronous crustal accretion in the Lewisian complex of northwest Scotland. Tectonophysics, 161, 245-256. 
Whitehouse, M.J. 1990. An early-Proterozoic age for the Ness anorthosite, Lewis, Outer Hebrides. Scottish Journal of Geology, 26, 131-136.

Whitehouse, M.J. 1993. The age of the Corodale Gneisses, South Uist. Scottish Journal of Geology, 29, 1-7.

Whitehouse, M.J. \& Bridgwater, D. 2001. Geochronological constraints on Palaeoproterozoic crustal evolution and regional correlations of the northern Outer Hebridean Lewisian complex, Scotland. Precambrian Research, 105, 289-314.

Whitehouse, M.J. \& Robertson, C.J. 1995. Isotopic evolution of the Lewisian Complex of Tiree, Inner Hebrides and correlation with the mainland. Scottish Journal of Geology, 31, 131-137.

Whitehouse, M.J., Fowler, M.B. \& Friend, C.R.L. 1996. Conflicting mineral and whole-rock Sm-Nd ages from the late Archaean Lewisian Complex of northwest Scotland: implications for geochronology in polymetamorphic high-grade terrains. Geochimica et Cosmochimica Acta, 60, 3085-3102.

Whitehouse, M.J., Claesson, S., Sunde, T. \& Vestin, J. 1997. Ion microprobe $\mathrm{U}-\mathrm{Pb}$ zircon geochronology and correlation of Archaean gneisses from the Lewisian Complex of Gruinard Bay, northwestern Scotland. Geochimica et Cosmochimica Acta, 61, 4429-4438.

WiLliams, I.S. 1998. U-Th-Pb geochronology by ion microprobe. In: McKibBEN, M.A., Shanks, W.C.P. III \& Ridley, W.I. (eds) Applications of Microanalytical Techniques to Understanding Mineralizing Processes. Reviews in Economic Geology, 7, xx-xxx.

WitTy, G. J. 1975. The geochemistry of the Roneval anorthosite, S. Harris, Scotland. $\mathrm{PhD}$ thesis, Imperial College, University of London.

Zhu, X.-K., O'Nions, R.K., Belshaw, N.S. \& GibB, A.J. 1997. Lewisian crustal history from in situ SIMS mineral chronometry and related metamorphic textures. Chemical Geology, 136, 205-218.

Received 29 September 2003; revised typescript accepted 23 June 2004.

Scientific editing by Alex Maltman 